\title{
THE EFFECT OF ARTIFICIAL VENTILATION ON FUNCTIONAL RESIDUAL CAPACITY AND ARTERIAL OXYGENATION
}

\author{
II Comparison of Spontaneous Respiration and Artificial Ventilation at Similar \\ Arterial Carbon Dioxide Tensions, Tidal Volumes and Inspiratory Gas Flow \\ Rates
}

\author{
D.S. Arthur, A.K. Mathur, H.I.A. Nisbet, and G.A. VolgYesi
}

\section{INTRODUCTION}

Artificial ventilation may produce undesirable effects upon the circulation, pulmonary gas exchange and pulmonary mechanics. ${ }^{1,2}$ It is uncertain how many of these effects are caused by artificial ventilation itself. Many may be due to changes in arterial carbon dioxide tension $\left(\mathrm{Pa}_{\mathrm{CO}_{2}}\right)$, or the pattern of ventilation or the use of different anaesthetic and muscle relaxant drugs.

We have compared cardiac output, gas exchange and pulmonary mechanics during spontaneous breathing and artificial ventilation, under conditions which allowed us to eliminate some of these variables.

\section{MEthoD}

Nine beagle dogs were lightly anaesthetized with pentobarbitone in doses which permitted $\mathrm{Pa}_{\mathrm{CO}_{2}}$ to remain within limits described as normal. ${ }^{3,4}$ We inserted a cuffed tracheal tube and an oesophageal balloon, and connected the tracheal tube to a pneumotachograph so that, with a differential pressure transducer and an amplifier/recorder system, we could measure tidal volume $\left(V_{T}\right)$, gas flow rates and lung compliance $\left(\mathrm{C}_{\mathrm{L}}\right)$. The pneumotachograph was connected to a breathing circuit and valve which permitted collection of expired gas and measurement of the functional residual capacity (FRC) during both spontaneous breathing and artificial ventilation. ${ }^{5.6}$ We measured expired gas volume $\left(\mathrm{V}_{\mathrm{F}}\right)$ and its oxygen and carbon dioxide content. An artery was cannulated in order to permit withdrawal of blood for measurement of arterial oxygen tension $\left(\mathrm{Pa}_{\mathrm{O}_{2}}\right), \mathrm{Pa}_{\mathrm{CO}_{2}}$, and $\mathrm{pH}$ and estimation of cardiac output $(\dot{Q})$ by means of the dye dilution technique. Values for $\mathrm{Pa}_{0,2}, \mathrm{~Pa}_{\mathrm{C}_{0,2},}$ and $\mathrm{pH}$ were corrected for changes in the dog's temperature, which were minimized by placing the dog on a heated blanket. A central vein was cannulated in order to inject the dye. This injection was always made at the same phase of respiration, namely at FRC. The dogs were permitted to breathe air. If after two hours of anaesthesia $\mathrm{Pa}_{\mathrm{co}}$, was within normal limits, we made measurements of $V_{\mathrm{T}}$, inspiratory flow rate $\left(\dot{\mathrm{V}}_{\mathrm{I}}\right), \mathrm{C}_{\mathrm{I}}, \mathrm{FRC}, \mathrm{V}_{\mathrm{E}}, \dot{\mathrm{Q}}$, and

From the Department of Anaesthesia, Research Institute, Hospital for Sick Children, Toronto, and the University of Toronto, Toronto, Ontario, Canada.

Supported in part by a grant from the Canadian Medical Research Council. Some of the equipment used in this study was purchased with funds from the Red Cross Youth, Ontario. 
arterial blood gas values. The oxygen and carbon dioxide contents of expired gas were then measured. From these measurements we calculated dead space to tidal volume ratio $\left(\mathrm{V}_{\mathrm{D}} / \mathrm{V}_{\mathrm{T}}\right)$, the alveolar gas tension for oxygen $\left(\mathrm{PA}_{\mathrm{A}_{2}}\right)$ and the gradient between it and that in arterial blood $\left(\mathrm{AaDo}_{2}\right)$.

When these measurements during spontaneous breathing were complete, the dog was artificially ventilated at the same tidal volume and inspiratory rate. $\mathrm{Pa}_{\mathrm{CO}_{2}}$ was adjusted to the value measured during spontaneous respiration by controlling the frequency of ventilation (f). After one hour of artificial ventilation the respiratory and cardiovascular measurements were repeated.

The significance of changes in these functions following artificial ventilation was assessed by means of the paired t-test. Five dogs were studied supine, and four in the lateral position. As the effect of artificial ventilation was similar in these positions, the results were not subdivided.

\section{Results}

$\mathrm{Pa}_{\mathrm{CO}}$ : values during artificial ventilation were very close to those during spontaneous ventilation. In order to maintain this constant $\mathrm{Pa}_{\mathrm{CO}_{2}}$, however, an increase in $V_{E}$ was required because $V_{D} / V_{T}$ rose.

No significant changes in $\mathrm{FRC}, \dot{Q}$, or $\mathrm{C}_{\mathbf{L}}$ during artificial ventilation were noted, but $\mathrm{Pa}_{\mathrm{O}_{2}}$ increased and $\mathrm{A}-\mathrm{aD}_{\mathrm{O}_{2}}$ decreased significantly.

\section{Discussion}

The only undesirable effect of artificial ventilation encountered in this study was a moderate increase in $V_{D} / V_{T}$. Since the inhalational anaesthetic agents were not used, and $\mathrm{Pa}_{\mathrm{CO}_{2}}$ was controlled, and we did not change the pattern of ventilation, it is not too surprising that $\dot{Q}, C_{L}$ and FRC remained unchanged. This supports previous reports which suggest that large falls in $\mathrm{C}_{\mathrm{L}}$ and $\mathrm{FRC}$ in ventilated subjects are mainly due to anaesthesia, and not to artificial ventilation. ${ }^{7}$

The increase in $V_{D} / V_{T}$ during artificial ventilation may in part be due to an increase in anatomical dead space $^{8}$ and in part to more even distribution of inspired gas." A greater proportion of inspired gas is wasted in dead space. When we compensated for this wastage by an increase in $\mathrm{V}_{\mathrm{E}}$, so that $\mathrm{PaCO}_{2}$ remained constant, there was a small but significant improvement in arterial oxygenation.

This increase in $\mathrm{Pa}_{\mathrm{O}}$ and the associated decrease in $\mathrm{A}-\mathrm{aD}_{0_{2}}$ were not accompanied by a change in FRC. The relationship between FRC and $A-\mathrm{aD}_{\mathrm{O}_{2}}$ is unpredictable as the gradient depends upon oxygen consumption and cardiac output among other factors. If a rise in cardiac output and a fall in oxygen consumption occurs, the arterial-mixed venous oxygen content difference will decrease so that blood which is shunted through badly perfused areas of the lung will contain more oxygen and arterial oxygenation will increase.

In our experiments a small rise in mean cardiac output occurred during artificial ventilation and presumably was accompanied by a small fall in oxygen consumption, due to reduced activity of the respiratory muscles. Such a combination of circumstances could explain the unexpected improvement in arterial oxygenation. 
TABLE

Changes in Cardiovascular and Respiratory Function During Artifictal Ventilation (mean/standard deviation/P)

\begin{tabular}{|c|c|c|c|}
\hline & Spontaneous Breathing & & Artificial Ventilation \\
\hline $\mathrm{PaCO}_{2}$ & $\begin{array}{c}40.4 \\
1.85\end{array}$ & NS & $\begin{array}{r}39.7 \\
1.0\end{array}$ \\
\hline$V_{E}(m l)$ & $\begin{array}{r}1797 \\
332\end{array}$ & $<0.006$ & $\begin{array}{r}2016 \\
340\end{array}$ \\
\hline$V_{D} / V_{T}$ & $\begin{array}{l}0.28 \\
0.07\end{array}$ & $<0.001$ & $\begin{array}{l}0.37 \\
0.07\end{array}$ \\
\hline$Q(L / \min )$ & $\begin{array}{l}2.81 \\
0.79\end{array}$ & NS & $\begin{array}{l}2.88 \\
0.85\end{array}$ \\
\hline $\mathrm{C}_{\mathrm{L}}\left(\mathrm{ml} / \mathrm{cm} \mathrm{H} \mathrm{H}_{2} \mathrm{O}\right)$ & $\begin{array}{l}32.85 \\
14.13\end{array}$ & NS & $\begin{array}{l}39.35 \\
14.40\end{array}$ \\
\hline $\mathrm{FRC}(\mathrm{ml})$ & $\begin{array}{l}397 \\
62.4\end{array}$ & NS & $\begin{array}{l}402 \\
73.5\end{array}$ \\
\hline $\mathrm{Pa}_{2}(\mathrm{~mm} \mathrm{Hg})$ & $\begin{array}{r}85.7 \\
3.3\end{array}$ & $<0.01$ & $\begin{array}{r}92.8 \\
3.9\end{array}$ \\
\hline $\mathrm{A}-\mathrm{aD}_{\mathrm{O}_{2}}$ & $\begin{array}{c}16.05 \\
4.8\end{array}$ & $<0.01$ & $\begin{array}{l}9.67 \\
4.76\end{array}$ \\
\hline
\end{tabular}

NS = not significant

\section{Conclusions}

In dogs anaesthetized with pentobarbitone and ventilated only with air, artificial ventilation increases $V_{\mathrm{D}} / \mathrm{V}_{\mathrm{T}}$, but need not reduce cardiac output, lung compliance, functional residual capacity or arterial oxygenation if values for tidal volume and inspiratory flow rate are unchanged from those measured during spontaneous breathing, and arterial carbon dioxide tension remains unchanged and within normal limits. This suggests that in animals with normal lungs, it may be possible to avoid all the undesirable effects of a short period of artificial ventilation except for an increase in $V_{D} / V_{T}$.

\section{SUMMARY}

We have compared cardiac output, gas exchange and pulmonary mechanics during spontaneous breathing and artificial ventilation under conditions which kept $\mathrm{Pa}_{\mathrm{Co}_{2}}$ within the normal range and maintained constant tidal volume and inspired gas flow rate.

In dogs anaesthetized with pentobarbitone and ventilated with air, artificial ventilation increased $V_{D} / V_{T}$ but did not reduce $\dot{Q}, F R C$, or $C_{L} . P_{O_{2}}$ increased and $\mathrm{A}-\mathrm{aD}_{\mathrm{O}_{2}}$ decreased during artificial ventilation, perhaps because of a small increase in $\dot{Q}$ and a small decrease in oxygen consumption. It appears that many of the reported deleterious effects of artificial ventilation may be due to the use of other anaesthetic agents and patterns of ventilation, and to changes in $\mathrm{Pa}_{\mathrm{CO}_{2}}$.

\section{RÉSUMÉ}

Nous avons comparé le débit cardiaque, les échanges gazeux et la dynamique pulmonaire lors de respiration spontanée et de ventilation contrôlée dans des con- 
ditions qui nous permettaient de garder une $\mathrm{Pa}_{\mathrm{CO}_{2}}$ dans les limites normales et de ventiler avec des volumes courants et un débit de gaz inspirés constants.

Chez des chiens anesthésiés avec du pentobarbital et ventilés avec de l'air, la ventilation artificielle a augmenté vd/vt, mais n'a pas diminué $\dot{Q}, F R C$, ou $C_{L}$. L'augmentation de $\mathrm{Pa}_{\mathrm{O}_{2}}$ et la diminution de $\mathrm{A}-\mathrm{aD}_{\mathrm{O}_{2}}$, pourraient être dues à l'augmentation légère du $\hat{Q}$ et à une diminution légère de la consommation $\mathrm{d}^{\prime} \mathrm{O}_{2}$. Il semble que plusieurs des effets nocifs rapportés concernant la ventilation artificielle seraient dûs à l'emploi de d'autres agents anesthésiques et d'autres types de ventilation, et à des changements de $\mathrm{Pa}_{\mathrm{CO}_{2}}$.

\section{REFERENCES}

1. FaIRley, H.B. Artificial ventilation. In: Scientific Foundations of Anaesthesia, C. Scurr and S.A. Feldman, Eds. London, Heinemann, pp. 192-199 (1970).

2. Mushin, W.W., Rendell-Baker, L., Thomson, P.W., \& Mapleson, W.W. Automatic ventilation of the lungs, 2nd ed. Oxford, Blackwell Scientific Publications, pp. 9-18 (1969).

3. Feigl, E.O. \& D'Alecy, L.G. Normal arterial blood $\mathrm{pH}$, oxygen and carbon dioxide tensions in anesthetized dogs. J. Appl. Physiol. 32: 152 (1972).

4. Pickefell, J.A., Durin, S.E., \& Elliot, J.C. Normal respiratory parameters of unanesthetized beagle dogs. Lab. Anim. Sci. 21: 677 (1971).

5. Dobrinson, T.L., Nisbet, H.I.A., Pelton, D.A., \& Volgyesi, G.A. Functional residual capacity (FRC) and compliance in anaesthetized paralysed children. Part $\mathrm{I}$ : in vitro tests with the helium dilution method of measuring FRC. Can. Anaes. Soc. J. 20: 310 (1973).

6. Volgyesi, G.A. \& Nisbet, H.I.A. A new piston ventilator for use in respiratory studies. Can. Anaesth. Soc. J. 19: 662 (1972).

7. Dobbinson, T.L., Nisbet, H.I.A., Pelton, D.A., Levison, H., \& Volgyesi, G.A. Functional residual compacity (FRC) and compliance in anaesthetized paralysed children. Part II, Clinical results. Can. Anaesth. Soc. J. 20: 322 (1973).

8. Dery, R., Pelletier, J., \& Jacques, A. Observations on anatomical dead space during general anaesthesia. Can. Anaesth. Soc. J. 11: 476 (1964).

9. Rehder, K., Hatch, D.J., Sessler, A.D., \& Fowler, W.S. The function of each lung of anesthetized and paralyzed man during mechanical ventilation. Anesthesiology 37: 16 (1972). 